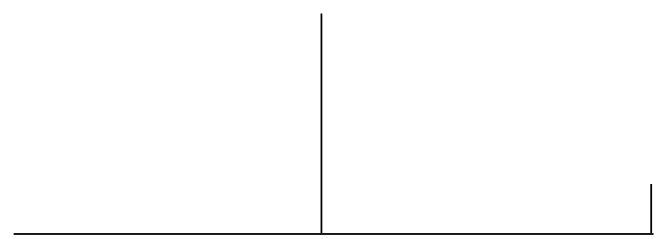

Rev. Latinoam. Psicopat. Fund., São Paulo, v. 15, n. 4, 923-925, dezembro 2012

Psicanálise compreensiva: uma concepção de conjunto

Walter Trinca

São Paulo: Vetor, 2011, 436 págs.

\title{
Psicanálise compreensiva: uma concepção de conjunto
}

A proposta pioneira de Trinca (2011), no livro Psicanálise compreensiva: uma concepção de conjunto consiste na apresentação de um modelo metodológico denominado "sistema geral compreensivo" que abarca as inúmeras possibilidades das atividades mentais e tem como objetivo elucidar e unificar as 'perturbações psíquicas' e os processos de 'expansão de consciência' utilizando como critério a análise do grau de contato que o indivíduo tem com o 'ser interior'.

Esse modelo tem seus pilares na prática clínica e na teoria psicanalítica, porém, trata-se de uma 'psicanálise compreensiva', voltada à concepção do 'ser interior', concebendo o indivíduo como um ser total, e busca apreender a 'inter-relação de alguns fatores' que compõem a vida mental e as possíveis implicações emocionais decorrentes. Assim, essa visão psicanalítica pode ampliar a prática clínica, a formulação e a articulação do pensamento clínico. 
Trinca pressupõe que as 'perturbações psíquicas' são decorrentes do 'distanciamento de contato'. O autor entrelaça teoria e material clínico, demonstrando que o distanciamento de contato produz repercussões no self, modificando sua atuação e que o exame minucioso dessas perturbações retrata o fator que exerce maior influência no self. Para facilitar a compreensão do leitor, o autor esclarece o modo de atuação da 'constelação do inimigo interno', da 'fragilidade' e da 'sensorialidade do self', da 'angústia de dissipação do self', da 'estruturação inconsciente', e a dinâmica desses fatores corroborando com o distanciamento de contato. Aborda ainda a relevância desses fatores na produção dos sistemas mentais determinantes.

São retomados alguns conceitos, dentre os quais, o de 'ser interior', enquanto núcleo de existência, singular, alicerçado por forças vitais e que acompanha o indivíduo por toda a vida, iluminando o 'self na tentativa de mantê-lo como aliado no desenvolvimento 'saudável' do indivíduo. O self, enquanto instância psíquica que contém os elementos da personalidade, e que além de receber influências do ser interior também é invadido e 'pressionado' por diferentes partes da mente, tornando-se um espaço de conflitos se não estiver em sintonia com o ser interior.

Ilustra através de um "eixo de contínuo de contato" a classificação dos estados: "consciente', "inconsciente" e "oclusivo", e em cada um deles, se o nível de contato estabelecido com o 'ser interior' é alto ou baixo e as implicações decorrentes. Salienta que no 'estado oclusivo' ocorre maior afastamento de contato com o 'ser interior' ocasionando dificuldades emocionais mais graves. Apresenta alguns fatores considerados responsáveis pelo 'distanciamento de contato'. Esclarece a linha de raciocínio que percorreu na elaboração desse modelo que permite a compreensão dos processos psíquicos, ampliando as possibilidades no atendimento clínico, ao facilitar a compreensão do aspecto estrutural e da dinâmica retratada pelo paciente.

As conjecturas realizadas por Trinca equiparam os sistemas mentais determinantes às perturbações psíquicas facilitando a visualização da classificação das mesmas no sistema geral compreensivo apresentado.

No decorrer dos capítulos, Trinca realiza a interlocução entre a visão psicanalítica sugerida através do modelo, alguns conceitos psicanalíticos clássicos e material decorrente de atendimentos clínicos, possibilitando a compreensão do leitor. Dentre esses conceitos, aborda e ilustra como a pulsão de morte atua no self e repercute na vida emocional do indivíduo, sob a denominação de 'constelação do inimigo interno', explicita o papel da angústia como elemento que incrementa os fatores básicos na formação dos 'sistemas mentais determinantes'. Reproduz situações clínicas colocando em evidência o fator preponderante de algumas perturbações psíquicas como o ciúme, a rivalidade, a voracidade, a inveja, a drogadição, o falso self, a depressão, a explosividade psicótica, e outras. 


\section{RESENHA}

DE LIVROS

A riqueza de detalhes dada à composição teórica do modelo proposto permite ao profissional, organizar a prática clínica e facilitar ao paciente a apropriação dos conteúdos que representam o 'ser interior' e os que são oriundos da manifestação do self em conflito.

\section{Maria IZiLda Soares Martão}

Mestre e doutora em psicologia clínica pela Universidade de São Paulo - USP (São Paulo, SP, Br); Psicóloga clínica.

Rua Rui Barbosa, 333 - Bairro Boa Vista

09190-370 Santo André, SP, Br.

Fone: (11) 4990-1300 (coml)

Rev. Latinoam. Psicopat. Fund., São Paulo, v. 15, n. 4, p. 923-925, dezembro 2012 